\title{
EFFECT OF BIOGEN-ZINC SUPPLEMENTATION ON SOME PRODUCTION, DIGESTION, RUMEN FERMENTATION AND SOME BLOOD PARAMETERS IN BUFFALO
}

\author{
Kh. I. I. Zeedan ${ }^{1}$, O. M. El-Malky ${ }^{2}$, O. F. Komonna ${ }^{3}$, M. A. Abdel-Latif ${ }^{2}$ \\ and Ebtehag I. M. Abouelenin ${ }^{1}$
}

1- Department of Animal Nutrition Research.

2- Department of Buffalo Research.

3- Department of Sheep and Goats Research.

Animal Production Research Institute, Agricultural Research Centre, Dokki, Giza, Egypt

\section{SUMMARY}

Twelve buffalo calves of 16-month of age were divided into three comparable groups, 4 animals in each. Average body weight at the beginning of the experiment was $242 \pm 3 \mathrm{~kg}$ for the three groups (213days). The present experiment lasted for 7 months. The main use of Biogen-Zinc in the present study as a probiotic or a Direct Fed Microbial (DFM) and zinc source as zinc methionine, is used as a feed additive for fattening buffalo calves. Concentrate feed mixture (CFM), berseem hay (BH) and rice straw (RS) were given to buffalo as a control ration (RI) without additive, while the other groups $R 2$ and $R 3$ received the control ration with Biogen-Zinc (BZ) at levels of $0.8 \mathrm{~g} / \mathrm{h} / \mathrm{d}(40 \mathrm{mg} \mathrm{Zn})$ and $1.6(80 \mathrm{mg} \mathrm{Zn}) \mathrm{g} / \mathrm{h} / \mathrm{d}$., respectively. Rumen fluid samples were collected before-feeding and then at 2, 4 and 6 hrs after feeding. Blood samples were collected from all animals at $4 \mathrm{hr}$ post-feeding right of the three groups.

Results revealed that digestibility of almost all nutrients; TDN and DCP, daily gain and body weight were significantly higher with for the buffalo fed R3 and R2 than those receiving $R 1$. Ruminal $p H$ values of the tested groups $(R 2 \& R 3)$ were not affected. Concentration of ruminal NH3-N was significantly higher for the control group than that of the $R 2$ and $R 3$ groups, while VFA's concentrations were increased for the rations supplemented with Biogen-Zinc (R2 and R3) compared to the R1. Also, R2 and R3 exhibited increased concentrations for serum total protein, total lipids, triglycerides, cholesterol, $T_{3}$ and $T_{4}$.

Keywords: Buffalo, biogen, zinc methionine, digestibility, blood constituents

\section{INTRODUCTION}

Many countries tend to prevent the application of some feed additives for their side effects on human health. It is of interest to replace these feed additives with other products which have no bad effects on both animal and human health. The inclusion of specific compounds of natural or synthetic origin as performance promoters at minute amounts into compound feed is a common practice in the animal and poultry feed industry. These compounds, which are called feed additives can be classified into two categories: The first, those additives which are essential

Issued by The Egyptian Society of Animal Production 
for the optimal biological functioning of the animal such as vitamins and trace elements. The second category includes additives which are not essential for biological function, but have demonstrated a positive effect upon the animal including growth promoters, metabolic modifiers, probiotics and prophylactics (Namur et al., 1988).

Recently, there is a growing trend all over the world to use additives especially those of natural origin which will be in turn reflected on human welfare in the form of high share of protein and better health. One of the best feed additives not only for sheep rations but also for all ruminant rations is the probiotics or Direct Fed Microbials (DFM). DFM have been shown to increase the feed conversion efficiency and daily gain in feedlot cattle and improve health and performance of young calves (Krehbiel et al. 2003).

The term (DFM) have been defined as" a live microbial feed supplement, which beneficially affect the animal by improving its intestinal microbial balance (Fuller 1989). moreover, probiotics (bacterial or yeast) had a positive effect, these may be reducing antibiotic substances, inhibition harmful bacteria metabolism and reduce rumen pH (Edwards et al., 1990; Fuller, 1992 and Salem et al., 2004).

Yoon and Stern (1995) reported that microorganisms used as DFM's for ruminants include viable cultures of both fungi and bacteria. Regarding, the use of antibiotics and other growth stimulants in the animal feed industry which has been increased in recent years there is a great emphasis placed on disease prevention for reducing the residues of antibiotics and pathogens in meat and meat products. As result, interest in the effects of DFM on animal health and performance has increased.

There are different proposed mechanisms for the mode of action of DFM but the most accepted one is that DFM modifies the balance of intestinal microorganisms, adhere to intestinal mucosa and prevent the pathogen adherence or activation. Moreover, it influences the gut permeability, and modulates the immune function (Salimen and Isolauri, 1996; Holzapfel et aI., 1998). Moreover, in the study of AbuTarboush et al. (1996) confirmed that the adherence of 1. acidophilus 27SC to the gastrointestinal tract (GIT) was observed in young calves and the organisms used were apparently compatible with the GIT. The original concept for feeding bacterial DFM to livestock was based primarily on the beneficial potency on post rumination functions including the establishment of beneficial gut microflora, (Fuller, 1999).

Miles and Henry (1999) reported that zinc is known to be essential for the function and / or structure of several enzymes as dehydrogenases, peptidases, phosphatases, a transphosphorylase, transcarbamylase and carboxpeptidase. Zinc has numerous biological roles including protein metabolism and DNA synthesis (Freeman, 1983). It also, was found to be an essential component of both DNA and RNA polymereses. It is also vital for a variety of hormonal activities including growth hormone, glucagon, insulin, as well as sex hormones. Zinc is an essential element required for physiological function including immune and antioxidant functions and growth in humans and animals (Shay and Mangian, 2000). 1t is also necessary for immune competence (Barceloux, 1999). Zinc plays a role in hormone secretion especially those related to growth, reproduction, immune competence and stress (Close, I999). Zinc has indirect effects on essential fatty acids metabolism (Cunnane and Yang, 1997). 
However, in recent years, there has been considerable interest in feeding ruminants the organic trace minerals which increase the bioavailability of the mineral above that of the soluble inorganic form [Henry (1995), Rojas et al., (1995) and Luo et al. (1996)]. The metal complex or chelate is stable in the digestive tract and is thus protected from forming complexes with other dietary components which could inhibit its absorption (Formigoni et al., 1993 and Cao et al., 2002).

\section{MTERIALS AND METHODS}

This study was carried out at EL-Gemmaiza Experimental Station belonging to the Animal Production Research Institute, Agricultural Research Centre Giza Egypt.

Twelve (16-month old) buffalo calves were used in this study. Animals were divided according to their body weight into three comparable groups, 4 animals in each. Average body weight at the beginning of the experiment was $242 \pm 3 \mathrm{~kg}$ for the three groups to study the effect of Biogen-Zinc(BZ) on nutrients digestibility, growing performance and some blood parameters. Animals were fed individually according to Kearl (1982). The control ration consisted of concentrate feed mixture (CFM), berseem hay (BH) and wheat straw (W5) were given to buffalo (RI) without additives, while the other groups R2 and R3 received the control ration with BiogenZinc (BZ) at level $0.8 \mathrm{~g} / \mathrm{h} / \mathrm{d}(40 \mathrm{mg} \mathrm{Zn})$ and $1.6(80 \mathrm{mg} \mathrm{Zn}) \mathrm{g} / \mathrm{h} / \mathrm{d}$., respectively. Biogen-Zinc (BZ) $\{1 \mathrm{~kg}$ content $500 \mathrm{~g}$ of Biogen Bacillus subtilis nato over than $10^{11} \mathrm{CFU}+500 \mathrm{~g}$ of Zinc methionine $\}$, while zinc methionine which contains methionine hydroxy analogue and $10 \%$ zinc by production of IBEX International Co. (BZ) were well mixed with some of the ground co-op mix before feeding. Fresh water was offered to the animals three times a day.

Digestibility trials were carried out at the middle of the feeding trials using four buffalo calves from each group to determine the nutrients digestibility and nutritive value of the experimental rations. Acid insoluble ash (AlA) (Van Keulen and Young, 1977) was used as a marker for the determination of the nutrients digestibility. Digestibility of DM as well as all nutrientes was determined with the following equations:

$\%$ Nutrient digestibility $=100-(\%$ DM digestibility $x \%$ Nutrient in feces $/ \%$ Nutrient in feed).

At the mid-term of the experimental fecal samples were collected from the rectum twice daily every $12 \mathrm{hr}$ at 6:00 and 18:00 $\mathrm{hr}$ starting at the $3^{\text {rd }}$ day of the collection period. Feed and fecal samples were dried to a constant weight in a forced air oven, ground and kept for later analysis.

Blood samples were withdrawn from the left jugular vein of all animals at $4 \mathrm{hrs}$ after feeding. Blood samples were placed immediately in an ice bucket, allowed to clot and centrifuged at $4000 \mathrm{rpm}$ for 20 minutes to obtain plasma. Plasma was stored frozen at $\left(-20^{\circ} \mathrm{C}\right)$ for later analysis.

Rumen fluid samples were collected for four days at the end of the last digestibility trial from all animals using stomach tube attached to a vacuum pump, before-feeding and then at 2, 4 and $6 \mathrm{hrs}$ post - feeding. Ruminal $\mathrm{pH}$ was measured immediately after collection using a digital $\mathrm{pH}$ meter. Rumen fluid was strained through four layers of cheesecloth into plastic containers and kept for later analysis. 
The determination of dry matter (DM). organic matter (OM), crude protein $(\mathrm{CP})$, crude fiber $(\mathrm{CF})$, ether extract (EE) and ash in the feed and feces were carried out according to the A.O.A.C. (1990). Ammonia-nitrogen determination was carried out as soon as possible using the steam distillation method described by Ahmed (1976). Total volatile fatty acids (VFA's) were measured recording to A.O.A.C. (1990). Total Lipids (TL), triglycerides (TG), cholesterol $(\mathrm{CH})$, total protein (TP), albumin, globulin, AST, ALT, Triiodothyronine $\left(\mathrm{T}_{3}\right)$ and Thyroxin $\left(\mathrm{T}_{4}\right)$ in plasma were determined using commercial kits. Data were analyzed using GLM procedures of the SAS (SAS, 1996). Means were separated by using Duncan's multiple range test (Duncan, 1955).

\section{RESULTS AND DISCUSSION}

\section{Chemical composition of feedstuffs:}

In general, the present results of the chemical composition values of $\mathrm{CFM}, \mathrm{BH}$, $\mathrm{B}-\mathrm{Z}$ and RS (Table 1) are within the normal ranges reported in Egypt by several workers (Baraghit, et al. 2003, Saleh, et al. 2005 and El-Hosseiny, et al., 2008 ).

Table 1. The chemical composition of feed ingredients and the calculated composition of the experimental diets

\begin{tabular}{|c|c|c|c|c|c|c|c|c|}
\hline \multirow{2}{*}{$\begin{array}{l}\text { Items } \\
\text { Items }\end{array}$} & \multicolumn{8}{|c|}{ Chemical composition an DM basis $(\%)$} \\
\hline & DM & $\mathbf{O M}$ & $\mathbf{C P}$ & $\mathbf{C F}$ & $\mathbf{E E}$ & Ash & NFE & ZN mg \\
\hline \multicolumn{9}{|c|}{ Chemical composition of the ingredients : } \\
\hline $\mathrm{CFM}^{*}$ & 89.53 & 92.61 & 14.18 & 12.38 & 4.20 & 7.39 & 61.85 & 49.8 \\
\hline $\mathrm{BH}$ & 90.22 & 80.55 & 12.52 & 24.96 & 2.23 & 13.45 & 40.84 & 21.5 \\
\hline RS & 88.11 & 84.57 & 2.85 & 41.17 & 1.29 & 18.98 & 39.26 & 19.64 \\
\hline $\mathrm{BZ}$ & 94.95 & 94.69 & 24.1 & 3.26 & 5.5 & 15.7 & 61.83 & - \\
\hline \multicolumn{9}{|c|}{ Calculated chemical composition of tested rations: } \\
\hline R1 & 89.38 & 88.59 & 11.58 & 20.54 & 3.24 & 10.92 & 53.13 & \\
\hline R2 & 89.40 & 88.64 & 11.70 & 20.38 & 3.25 & 10.81 & 53.32 & \\
\hline R3 & 89.42 & 88.70 & 11.82 & 20.09 & 3.28 & 10.63 & 53.51 & \\
\hline
\end{tabular}

*CFM; concentrate feed mix contained in percentage ; \%yellow corn ,37; undecortecated cotton seed , 30; wheat bran,20; rice bran, 6.5 ; molasses ,3 ; limestone, 2.5 ; common salt, 1 .

$\mathrm{BH}$, Berseem hay., RS, Rice straw, BZ, Biogen-Zinc .

\section{Nutrients digestibility and nutritive values}

Data in Table (2) indicated that Biogen-Zinc (R3) at level $1.6(80 \mathrm{mg} \mathrm{Zn)} \mathrm{gm/h/d}$ supplementation increased $(\mathrm{P}<0.01)$ all nutrients digestibility compared to control (R1), while R3 was higher than Biogen-Zinc(R2) at level 0.8 (40 mg Zn) gm/h/d , except with OM, EE and NFE. The improvement in digestibility coefficients could be illustrated on the basis that zinc methionine can play indirect role to stimulate anaerobic fermentation of organic matter that improve the utilization efficiency or nutrients and direct role to improve digestion in abomasums. These results were in agreement with those obtained by Mousa and EL-Sheikh (2004). They reported that different levels of zinc to buffalo calves rations significantly $(\mathrm{P}<0.05)$ increased the 
digestibility of $\mathrm{CP}, \mathrm{CF}, \mathrm{EE}$ and NFE when compared to control ration. Aly et al., (2005) showed that the apparent digestibility of DM, OM, CP, CF, EE and NFE were significantly $(\mathrm{P}<0.05)$ improved with added protected methionine in the ration of goats. Durand and kawashima (1980) concluded that addition of $50 \mathrm{mg} \mathrm{Zn} \mathrm{/} \mathrm{kg}$ $\mathrm{OM}$ to rations would optimize microbial metabolism and consequently led to improve DM, OM. CP, CF, EE and NFE digestibilities, Such improvement in nutrients digestibility and absorption in the abomasums by zinc addition may be attributed to increasing the activity of some enzymes related to the digestion of carbohydrates, fats and protein (amylase, lipase, trypsinogen, chemotrypsinogen and some peptidases), since these enzymes are known to be $\mathrm{Zn}$-dependent (Banerjee,1988 and $\mathrm{Lu}$ and Combs, 1988) and the increase of protein and energy utilization as indicated by the improvement of rumen traits (Valdes et al., 2000, and Salem, 2003). Also, improvement of most nutrient digestibility resulted in increasing the nutritive value of rations containing Biogen. Probiotic bacteria species such as $B$. subtilis have been shown to produce digestive enzymes as amylase, protease and lipase, which may enrich the concentration of intestinal digestive enzymes (Lee and Lee, 1990).

Table 2. Digestion coefficient and nutritive values of the experimental rations fed to buffalo calves

\begin{tabular}{lcccccccc}
\hline \multirow{2}{*}{ Items } & \multicolumn{9}{c}{ Digestibilities \% } & \multicolumn{3}{c}{ Feeding values \% } \\
\cline { 2 - 9 } & DM & OM & CP & CF & EE & NFE & TDN & DCP \\
\hline R1 & $67.56^{\mathrm{c}}$ & $70.82^{\mathrm{b}}$ & $57.54^{\mathrm{c}}$ & $51.86^{\mathrm{c}}$ & $89.69^{\mathrm{b}}$ & $74.63^{\mathrm{b}}$ & $65.84^{\mathrm{c}}$ & $6.89^{\mathrm{c}}$ \\
R2 & $71.25^{\mathrm{b}}$ & $72.64^{\mathrm{ab}}$ & $66.53^{\mathrm{b}}$ & $58.67^{\mathrm{b}}$ & $92.39^{\mathrm{ab}}$ & $76.87^{\mathrm{ab}}$ & $71.56^{\mathrm{b}}$ & $7.87^{\mathrm{b}}$ \\
R3 & $73.93^{\mathrm{a}}$ & $75.92^{\mathrm{a}}$ & $71.18^{\mathrm{a}}$ & $62.32^{\mathrm{a}}$ & $95.82^{\mathrm{a}}$ & $80.95^{\mathrm{a}}$ & $75.93^{\mathrm{a}}$ & $8.52^{\mathrm{a}}$ \\
\hline
\end{tabular}

$\mathrm{a}, \mathrm{b}$, ..etc. means within the same column with different superscripts are significantly different $(\mathrm{P}<0.05)$.

It is obvious (Table 2) that BZ supplementation improved significantly $(\mathrm{P}<0.05)$ the nutritive value as TDN and DCP in both of R2 and R3 than R1. Improvement of TDN and DCP might be due to the higher values of digestibility values of all nutrients by supplementation with different levels of BZ. This finding agree with the results of (Mousa and Sheikh, 2004; Saleh et al., 2005 and Shams, 2008).

\section{Rumen parameters:}

Ruminal $\mathrm{pH}$ value is one of the most important factors, which affect microbial fermentation in the rumen and influenced its functions. Data presented in Table (3) illustrated that the differences among BZ levels on $\mathrm{pH}$ value were not significant, and the averages were nearly similar in all groups experiments (Table 3). But $\mathrm{pH}$ value was decreased after the 0.00 time feeding in all groups. Similar results were reported by (Saleh et al., 2005 and Shams, 2008).

On the other hand, $\mathrm{NH}_{3}-\mathrm{N}$ concentration was significantly $(\mathrm{P}<0.05)$ decreased for buffalo calves fed supplemented with Biogen- Zinc (R2 and R3) compared to the control group $(\mathrm{R} 1)$, while ammonia- $\mathrm{N}$ was increased $(\mathrm{P}<0.05)$ at $4 \mathrm{hrs}$ post - feeding and then began to decrease again at 6 hrs. Post - feeding shown Table (3). These results are in agreement with those reported by (Saleh et al., 2005; Shakweer et al., 2005 and Shams, 2008). 
Table 3. Effect of Biogen-Zinc supplementation on some rumen liquor parameters of buffalo calves

\begin{tabular}{lcccc}
\hline \multicolumn{1}{c}{ Item } & Time & R1 & R2 & R3 \\
\hline pH & 0 & 6.56 & 6.52 & 6.50 \\
& 2 & 6.24 & 6.21 & 6.20 \\
& 4 & 6.10 & 6.07 & 5.99 \\
Ammonia-N mg/100ml & 6 & 5.83 & 5.80 & 5.79 \\
& 0 & $13.66^{\mathrm{a}}$ & $10.98^{\mathrm{b}}$ & $9.35^{\mathrm{c}}$ \\
& 2 & $14.86^{\mathrm{a}}$ & $12.56^{\mathrm{b}}$ & $10.84^{\mathrm{c}}$ \\
Total VFA meq/100ml & 4 & $16.63^{\mathrm{a}}$ & $14.54^{\mathrm{b}}$ & $11.93^{\mathrm{c}}$ \\
& 6 & $12.26^{\mathrm{a}}$ & $10.59^{\mathrm{b}}$ & $9.82^{\mathrm{c}}$ \\
& 0 & $7.84^{\mathrm{b}}$ & $8.94^{\mathrm{a}}$ & $9.10^{\mathrm{a}}$ \\
& 2 & $11.54^{\mathrm{b}}$ & $13.87^{\mathrm{a}}$ & $14.44^{\mathrm{a}}$ \\
& 4 & $14.51^{\mathrm{b}}$ & $15.67^{\mathrm{a}}$ & $15.87^{\mathrm{a}}$ \\
\hline a,b,c Means with different superscripts within each row for each parameter are significantly different. \\
(P<0.05). & 6 & $7.70^{\mathrm{b}}$ & $8.71^{\mathrm{a}}$ & $9.72^{\mathrm{a}}$
\end{tabular}

The decreased ruminal ammonia- $\mathrm{N}$ concentration may be attribute to the decreased ureolysis or increase in ammonia- $\mathrm{N}$ conversion to microbial protein because adding of zinc methionine (Putnam and Schwab,1994 and Arelovich et al., 2000). Lowest both ammonia-N concentration and $\mathrm{pH}$ value were noticed in $\mathrm{R} 3$ may be attributed to the high Biogen level $(1.6 \mathrm{~g} / \mathrm{h} / \mathrm{d})$ which was more efficient in encouraging ruminal lactic acid producing bacteria and other species that can convert ammonia-N into microbial protein synthesized. These results are in agreement with those reported by Salem et al. (2004), who indicated that probiotics (bacteria or yeast) had positive effect through lactic acid production on intestinal bacteria activities and inhibit harmful bacteria such as Escherichia coli-10 in the intestine of sheep.

Table (3) shows that the TVFA's of R3 and R2 were significantly $(\mathrm{P}<0.05)$ greater than that of $\mathrm{R} 1$ at all sampling times studied. While the TVFA's were increased at $4 \mathrm{hrs}$ post - feeding and then began to decreased again at $6 \mathrm{hrs}$. post feeding. Similar results obtained by (Saleh et al., 2005; Shakweer, et al., 2005; and Shams, 2008). In the present study, greater VFA's concentration with BZ groups may be due to the increase in all, OM, CP and CF digestibilities than the control group (Table, 2).

\section{Blood constituents :}

Data present in Table (4) show that TP, TL, Triglycerides, Cholesterol, T3 and T4 of R3 and R2 were significantly $(\mathrm{P}<0.05)$ greater than that of R1. Similar results were obtained by (Glade, 1991; Yousef et al., 1996; El-Ashry et a1., 2001; Mousa and EL-Sheikh 2004 and Shakweer, et al., 2005). The increase in blood serum protein with zinc methionine addition may be due to the increase in protein synthesis as a result of the elevation of anabolic hormone secretion that are responsible for utilization of amino acids and other physiological functions related to metabolic rate (Freeman, 1983 and El-Masry and Habeeb, 1989) and the decrease in the catabolic hormones such as glucocorticoid and catecholamine (Alvarez and Johnson, 1973 and 
Baillet et al., 1997). Also, Lawrence and Fowler (1997) reported that thyroid hormones influence the function of most organs and stimulate the basic metabolic rate through regulation of the metabolism of carbohydrates, proteins and lipids.

Table 4. Chemical analysis of blood serum of buffalo calves as affected by Biogen-Zinc supplementation

\begin{tabular}{lccc}
\hline \multicolumn{1}{c}{ Items } & R1 & R2 & R3 \\
\hline T. protein (g/dl) & $6.58^{\mathrm{c}}$ & $7.86^{\mathrm{b}}$ & $8.93^{\mathrm{a}}$ \\
Albumin (g/dl) & $3.02^{\mathrm{c}}$ & 3.35 & 3.51 \\
Globulin (g/dl) & $3.56^{\mathrm{c}}$ & $4.51^{\mathrm{b}}$ & $5.42^{\mathrm{a}}$ \\
Albumin: Globulin ratio & 0.85 & 0.74 & 0.65 \\
T. lipids (mg/dl) & $360^{\mathrm{c}}$ & $440^{\mathrm{b}}$ & $490^{\mathrm{a}}$ \\
ALT (IU/L) & 7.56 & 7.62 & 6.95 \\
AST (IU/L) & $8.48^{\mathrm{c}}$ & 8.57 & 8.39 \\
Triglycerides (mg/dl) & $21.23^{\mathrm{c}}$ & $27.36^{\mathrm{b}}$ & $33.58^{\mathrm{a}}$ \\
Cholesterol (mg/dl) & $180.50^{\mathrm{c}}$ & $280.62^{\mathrm{b}}$ & $315.62^{\mathrm{a}}$ \\
T3 (ug / dl) & $158.6^{\mathrm{c}}$ & $210.5^{\mathrm{b}}$ & $243.4^{\mathrm{a}}$ \\
T4 (ug / dl) & $8.52^{\mathrm{b}}$ & $9.15^{\mathrm{a}}$ & $9.82^{\mathrm{a}}$ \\
\hline
\end{tabular}

a,b,c Means with different superscripts within each row for each parameter are significantly different. $(\mathrm{P}<0.05)$.

Data in Table (4) showed that globulin was lower in R1 than R2 and R3. These results are in agreement with those reported by Abd EI-Gawad et al. (2002), who reported that yeast culture supplement induced an increase in serum globulin level in ruminant. Also, Mousa and El-Sheikh (2004) indicateed that the addition of 80 and $120 \mathrm{mg}$ zinc sulfate improved total protein and globulin.

No significant differences $(\mathrm{P}<0.05)$ were observed in AST(alanine aminotrandferase), ALT(aspartate aminotrandferase) and albumin among the three groups (Table 4).Values AST and ALT were within the normal range and indicated that the animals were generally in a good nutritional status and their livers were in a normal health condition. The same results agree with Abd EI-Khalek et al. (2000) who found that ALT and AST activity were not affected in Friesian calves supplemented with Lacto-Sacc yeast supplementation. Moreover, EI-Ashry et al. (2001); EI-Shamaa (2002) and Metwally et al. (2002), found that the addition of yeast culture to the diets for ruminants did not affect significantly ALT and AST activity. Piva et al. (1993), confirmed that blood albumin was not affected significantly by adding the yeast culture to the rations of lactating cows. These results may explain that Biogen-Zinc treatment is safe with liver functions and so it had not any harmful effect on liver tissues. The increase in blood studied constituents may be due to the role of Biogen as probiotic in improving all nutrient digestibility especially $\mathrm{CP}$ (Table, 2) and rumen parameters (Table, 3) of buffalo calves fed BZ, and also may be probably led to an increase in the absorption rate from the digestive tract, thus blood constituents of the supplemented animals reflected a corresponding increase of these values.

Performance of buffalo calves :

The change in body weight, total gain and daily gain of buffalo calves feed different levels of Biogen-Zinc are presented in Table (5). It is obvious that calves 
feed the R3 gained significantly $(\mathrm{P}<0.05)$ more than the other groups. Animals received $\mathrm{R} 2$ gained more $(\mathrm{P}<0.05)$ than $\mathrm{R} 1$. Improvement of growth performance with BZ may be due to positive effect of Biogen as natural growth promoter on rumen microbial activity and all nutrients digestibility. Also zinc methionine supplementation might lead to the improvement of the acid base balance (Hahn and Baker, 1993), The improvement in the activities of digestive enzymes (Izhboldina, 1994), propionate concentration and ruminal protozoa numbers (Froetschel et al.,1990), the increase in the efficiency of dietary protein utilization and nutrients metabolism (Banerjee, 1988) total protein and globulin in blood plasma (Bednarek et al., 1991) and immunity protection (Gross et al.,1979 and Hahn and Baker, 1993).

Table 5. Productive performance of buffalo calves as affected by the Biogen-Zinc supplementation levels

\begin{tabular}{lccc}
\hline Items & R1 & R2 & R3 \\
\hline No. of animals & 4 & 4 & 4 \\
Duration (day) & 213 & 213 & 213 \\
Initial weight (Kg) & 242.75 & 242.25 & 242.5 \\
Final weight (Kg) & $451.50^{\mathbf{c}}$ & $474.40^{\mathbf{b}}$ & $498.10^{\mathbf{a}}$ \\
Total gain (Kg) & $208.75^{\mathbf{c}}$ & $232.15^{\mathbf{b}}$ & $255.6^{\mathbf{a}}$ \\
Daily gain (g/h/d) & $980^{\mathbf{c}}$ & $1090^{\mathbf{b}}$ & $1200^{\mathbf{a}}$ \\
Daily feed DM intake Kg /h/d : & & & \\
CFM & 4.5 & 4.5 & 4.5 \\
W.S. & 1.5 & 1.5 & 1.5 \\
BH & 1.5 & 1.4 & 1.3 \\
Total DMI & 7.5 & 7.4 & 7.3 \\
Total TDNI & $4.94^{\mathbf{c}}$ & $5.30^{\mathbf{b}}$ & $5.54^{\mathbf{a}}$ \\
Total DCPI & $0.52^{\mathbf{c}}$ & $0.58^{\mathbf{b}}$ & $0.62^{\mathbf{a}}$ \\
$\quad$ Feed conversion (Kg/kg gain) : & & & \\
DM & $7.65^{\mathbf{a}}$ & $6.79^{\mathbf{b}}$ & $6.08^{\mathbf{c}}$ \\
TDN & 5.04 & 4.86 & 4.62 \\
DCP & 0.53 & 0.53 & 0.52 \\
\hline
\end{tabular}

$\mathrm{a}, \mathrm{b}, \ldots$ etc. means within the same row with different superscripts are significantly different $(\mathrm{P}<0.05)$.

Data in Table (5) concerning the DMI exhibited that the lowest values obtained were for the R2 and R3 groups compared to R1 group, but with no significant differences between groups. Pacheco - Rios et al. (1997) reported that dry matter intake tended to decrease when dairy cows diets were supplemented with 15 $\mathrm{g} / \mathrm{d}$ protected methionine or with $15 \mathrm{~g} / \mathrm{d}$ free methionine. The same results were noted by Pacheco - Rios et al. (1999) indicated that when protected methionine was given to dairy cows during mid and late lactation tended to decrease $(\mathrm{P}<0.09)$ dry matter intake.

The data of Table (5) show that the feed intake as $\mathrm{kg}$ TDN and DCP per head was increased with increasing level of BZ compared to R1. The results agree with the findings of Shakweer, et al. (2005).

Feed conversion as $\mathrm{kg} \mathrm{DM} / \mathrm{kg}$ gain: results showed that R3 group gained higher $(\mathrm{P}<0.05)$ weight than the other groups. Animals received R2 gained weight more $(\mathrm{P}<0.05)$ than $\mathrm{R} 1$. There were no significant differences between feed conversion as $\mathrm{kg}$ TDN and $\mathrm{kg}$ DCP / $\mathrm{kg}$ gain in all treatments. 


\section{CONCLUSIONS}

The study results indicated that using Biogen-Zinc is beneficial to rumen activities, digestion, growth performance, of buffalo calves compared with control. The combination of Biogen with zinc methionine as feed supplement appeared to be a satisfactory with rations for feeding buffalo calves.

\section{REFERENCES}

Abd El-Gawad, Eman, I.;G. M. Maharm; Faten, F. AbouAmmo and A. I. Fathia, 2002. Effect of yeast culture (Lacto-Sacc) supplementation on growth, some blood parameters and carcass quality of goats. Egypt. J. Appl. Sci., 17: 375-388.

Abd EI-Khalek; A. F. Mehrez and E. A. Omar, 2000. Effect of yeast culture (LactoSacc) on rumen activity, blood constituents and growth of suckling Friesian calves.Proc. Conf. Anim. Prod. The $21^{\text {th }}$ Century, Sakha, 18-20 April 2000, pp. 201-210.

Abu-Tarboush, H. M.; M. Y. AI-Saiady and A. H. Keir EI -Din, 1996. Evaluation of diet containing lactobacilli on performance, fecal coli form, and lactobacilli of young dairy calves. Anim. Feed Sci. Technol., 57: 39-49.

Ahmed, B. M. , 1976 . The use of non-protein nitrogenous compounds in rabbit rations. M. Sc. Thesis. Tanta Univ.

Alvarez, M. B. and H. D. Johnson, 1973. Environmental heat exposure on cattle plasma catechol arnine and glucocorticoid. J. Dairy Sci., 56: 189.

Aly,T.A. ; M. A. Al -Ashry; A . M. Kholif; H. M. El-Sayed ; H. A. El -Alamy and M. M. Khorshed, 2005. Effect of rumen - protected methionine and/or lysine supplementation to the ration on nutrients digestibility and on some rumen parameters of male Balady goats. Egyptian J. Nutr. and Feeds, 8: 41-51.

A. O. A. C., 1990. Association of Official Agricultural Chemists. Official Methods of Analysis. Washington D.C.

Arelovich, H. M.; F. N. Owens, G. W. Horn and J. A. Vizcarra, 2000. Effect of supplemental zinc and manganese on rurninal fermentation, forage intake and digestion by cattle fed prairie hay and urea. J .Anim .Sci., 78: 2972-2979.

Baillet, G., G. Cuzon. M, cosin and C. Kerlequer, 1997. Effect of dietary protein levels on growth of Penaeus Stylivostrisjuveniles. Nut. Abst. Rev., 68: 145.

Banerjee, G. C., 1988. Feeds and Principles of Animal Nutrition. 2nd Ed. Oxford and IBH Publishing Co. PVT. LTD., 636.

Baraghit, G. A., M. N. El- Kholy, S. S. Omar, B. M. Ahmed and kh. I. Zeedan, 2003. Effect of dietary fat sources on digestibility, rumen fermentation and blood parameters of buffalo calves. Egyptian J. Nutr. and Feeds, 6: 663 -674.

Barceloux, D.C. 1999. Zinc Toxicology .CIin. Toxicol, 37: 279.

Bednarek, D., M. Kondrachi and J. Krasucki, 1991. Effect of zinc on mineral, hematological and immunological indices in calves. Polskie Archiwum Vet., 31: 129.

Cao, J.; P. R. Henry; R.A.Holwerda; J. P.Toth; R. C. Littell; D. R. Miles and B. Ammerman, 2002. .Chemical characteristics and relative bioavailability of supplemental organic zinc source for poultry and ruminants. J. Anim .Sci. 78: $2039-2054$ 
Close, W. H., 1999. Organic minerals for pig: An update, Proceeding of Our industry Under the Microscope. Biotechnology Responds. Caltech's European, Middle Eastem and African Lecture .

Cunnane, S. C. and 1. Yang, 1997. Disruption of the metabolism of polyunsaturated fatty' acids (PUFA) during moderate zinc deficiency. In Fischer, P. W.F., L, Abbe, M.R., Cockell,K.A.A. and Gibson.RS.(ed).Proceeding of Ninth International Symposium on Trace Elements in Man and Animals. NRC Research Press, Ottwa, 604.

Duncan, D. B. 1955. Multiple range and multiple F-tests. Biometrics., 11: 1-42.

Durand, M. and R. Kawashima, 1980. Influence of minerals in rumen microbial digestion. In: Y. Ruckebusch and P. Thivend (Eds.). Digestive Physiology and Metabolism in Rurninants. pp. 375 - 408. AVI Pub. Co., Inc., Westport, CT.

Edwards, I. E.; T. Musvangwa, J. H. Topps and G. F. M. Paterson , 1990. The effect of supplemental yeast culture (Yea-Sacc) on patterns of rumen fermentation and growth

EI-Ashry, M. A., A. M. Kholif, H. A. EI-Alamy, H. M. El-Sayed and T. A. EIHamamsy, 2001. Effect of different yeast cultures supplementation to diet on the productive performance of lactating buffaloes. Egyptian J. Nutr. and feeds, 4: 2133.

El-Hosseiny, Hoda, M., KH. M. M. Mousa, H. B. Abou-Elella and O. A. Alama, 2008. Influence of some mineral additives on nutrients digestibility, performance and economic efficiency of growing camel young feed dietary silage. Proe. of Middle East \&: North Africa Conf for Future of Animal Wealth .pp. 305 -316.

EI-Masry, K. A. and A. A. Habeeb, 1989. Thyroid functions in lactating Friesian cows and water buffaloes under winter and summer Egyptian conditions. Proc. of $3^{\text {rd }}$ Egypt-British Conf. on Anim. Fish and Pou1t. Prod., Vol 2, Alex, Egypt, pp. 613.

El-Shamaa, I. S. 2002. Onset of puberty, semen production and blood constituents in crossbred male lambs as affected by dietary yeast culture addition. J. Agrie, Sci. Mansoura Univ., 27(7): 4589-4598.

Formigoni, A., P. Parisini and F. Corradi, 1993. The use of amino acid chelates in high production milk cows. In: A shmead ,H.D.(Ed).The roles of amino acid chelates in Animal Nutrition. Noyes Publication, Park Ridge, NJ,PP.170-186.

Freeman, B. M. 1983. Physiology and Biochemistry of Domestic Bowel. Vol 4, Academic Press, New York and London, pp. 181.

Froetschel, M. A., A. C. Martin, H. E. Amos and J. J. Evans, 1990. Effects of zinc sulfate concentration and feeding frequency on ruminal protozoa numbers, fermentation pattern and amino. acid passage in steers. J. Anim. Sci., 68: 2874.

Fuller, R. 1989. Areview probiotics in man and animals. J.Appl. Bacteriology., 66:365-378.

Fuller, R. 1992. Probiotics the Scientific basis. Probiotics for ruminants. $1^{\text {st }}$ Ed., pp. 315.

Fuller, R. 1999. Probiotics for farm animals. In: G. W. Tannock (ed.) probiotics-A Critical Review. P 15. Horizon Scientific Press, Wymondham, England.

Glade, M. J. 1991. Dietary yeast culture supplernentation of mares during late gestation and early lactation: Effect on mares and foal metabolites, amino acid and endocrine profiles. J. Equine Vet. Sci., 11: 167-171. 
Gross, R.L., N. Osolin, L. Fong and P.M. Newbom, 1979. Depressed immunological function in zinc deprived rats as rneasured by nitrogen response of spleen, thymus and peripheral blood. AM. Clin. Nutr ., 32: 1260.

Hahn, J. D. and O. R. Baker, 1993 . Growth and plasma zinc responses of young pigs fed pharma co logical levels of zinc. J. Anim. Sci, 71: 3020.

Henry, P. R. 1995. Manganese bioavailability . In : Ammerman, CB.,Baker, D.H.,Lewis, A.J.(Eds.). Bioavailability of Nutrients for Animals. Amino acids, minerals, and vitamins. Academic Press, San Diego, C.A., PP239-256.

Holzapfel, W. H., P. Haberer, J. Snel, U. Schillinger and J. H. J. Huisin't Veld, 1998. Overview of gut flora and probiotics. Int. J. Food Microbiol.,41:85-101.

Izhboldina, S. 1.1994 . Trace elements during rearing and fattening of young bulls. Zootekhniya, 33: 14.

Kearl. L. c. 1982. Nutrient requirements of ruminants in developing countries. International feedstuffs Institute, Utah Agrie. Expt. Stat. Utah State Univ., USA.

Krehbiel, C. R., S. R. Rust, G. Zhang and S. E. Gilliland, (2003. Bacterial direct fed microbial in ruminant diets performance response and mode of action. J. Anim. Sci., 81: EI20-E132.

Lawrence, T. L. J. and V.R. Fowler, 1997. Growth of Farm Animals. CAB International, Wallingford, Oxon OX10 8DE, UK. pp. 114.

Lee, S.Y. and B. H. Lee, 1990. Esterlytic and lipolytic activities of Lactobacillus casei-ubsp-casei LLG. J. Food Sci., 55: 119.

Lu, J. and G. F. Combs, 1988. Effect of excess dietary zinc on pancreatic exocrine function in the chick. J. Nut., 118: 681.

Luo, X. G., P.R. Henry, C. B. Ammerman and J . B. Madison, 1996 . Relative bioavailability of copper in a copper lysine complex or copper sulfate for ruminants as affected by feeding regimen. Anim. Feed Sci. and Technol., 57: 281289.

Metwally, A. M., I. S. El-Shamaa and M. Abd EI-Momin, 2002. Changes in some blood constituents, growth rate and rumen fermentation of growing lambs fed yeast culture. Second Int. Conf. On Anim.Prod. and Health in Semiarid Area. Fac. Env. Agrie. Sci., El-Arish, 115-131.

Miles, R. D. and P. R. Henry, 1999. Relative trace mineral bioavailability. In : Proceeding of the California Animal Nutrition Conference held on may 6,1999, Piccadilli Inn Hotels, Fresno, CA,PP1-24.

Mousa, Kh. M. M. and S. M. Sheikh, 2004. Effect of different levels of zinc supplementation on utilization of non-protein nitrogen and production performance of buffalo calves. J. Agric ., Sci. Mansoura Univ., 29: 3779.

Namur, A. P., J. Morel and H. Bichek, 1988. Compound animal feed and feed additives. In Deboer , F., H.BICHEL, eds. Livestock feed resources and feed evaluation in Europe. Elsevier.Sci. Publ., Amsterdam .

Pacheco - Rios, D., W. C. Mcnabb, J. P. Hill, T. N. Barry and D. D. S. Mackenzie, 1997. The effects of methionine supply upon milk composition and production of dairy cows in mid-Lactation. Proceedings of the New Zealand Society of Animal Production, 57: 147.

Pacheco-Rios, D., W.C. Mcnabb, J. P. Hill, T.N. Barry and D. D. S. Mackenzie, 1999. The effects of methionine supplementation upon milk composition and production of forage-fed dairy cows. Canadian Journal of animal science, 79: 235.

Piva, G., S. Belladonna, G. Fusconi and F. Sicbaldi, 1993. Effects of yeast on dairy 
cow performance, ruminal fermentation, blood components, and milk manufacturing properties. J. Dairy Sci., 76: 2717-2722.

Putnam, D. E. and C. G. Schwab, 1994 . Mode of action of yeast culture. J. Anim.Sci. ,72: Suppl. 2-5.

Rojas, L. X, L. R. McDwell, R. J.Cousins, F. G. Martin, N. S. Wilklnson, A. B. Johanson and J. B. Velasquez, 1995. Relative bioavailability of Two organic and two inorganic zinc sources fed to sheep J.AnimSci.73,1202- 1207.

Saleh, M. S., A. M. Metwally and M. Abd El-Momin, 2005. Effect of feeding rations supplemented with biogen on digestibility and performance of growing lambs. Egyptian. J. Nutr. And Feeds. 8: 635-646.

Salem, F. A. 2003. Effect of dietary silage source on feed intake, nutrients digestibility, some blood constituents and milk production in lactating buffaloes. Egypt. J. Nut. and Feeds, 6:5.

Salem, A. Z. M., M. M. El-Adawy, M. Z. M. Salem and A. A. Hassan, 2004 . Effect of Probiotics feed as additives on the activity of isolated and characterized lactic acid intestinal bacteria to inhibit Escherichia coli- 10 in sheep. Egyptian. J. Nutr. and Feeds. 7: 167.

Salimen, E. and E. Isolauri, 1996. Clinical uses of probioties for stabilizing the gut mucosal barrier: successful strains and future challenges. Antoine Leeuwenhoek 70: 347-358.

SAS ,1996. SAS user's guide: Statistics. SAS Inst. Inc. Cary NC.

Shakweer, I. M. E., A. A. M. EL-Mekass and H. M. EL-Nahas, 2005 . Effect of different levels of supplemented organic zinc source on performance of Friesian dairy cows. J. Agric. Sci. Mansoura Univ., 30 (6): 3001 - 3011.

Shams, A.S., 2008. Utilization of zinc methionine supplementation on milk production and somatic cell count in friesian cows. M.Sc. Thesis . Anim. Prod. Dept. Kafr El-Sheikh.

Shay, N. F. and H. F. Mangian, 2000 . Neurobiology of zinc-influenced eating behavior. J. Nutr., 130: 14935.

Valdes, C., M. D. Carro., M. J. Ranilla and J. S. Gonzu1ez, 2000. Effect of forage to concentrate ratio in complete diets offered to sheep on voluntary food intake and some digestive parameters. J. Anim. Sci., 70: 199.

Van Keulen, 1. and B. A. Young, 1977 . Evaluation of acid insoluble ash as a natural marker in ruminant digestibility studies. 1. Anim. Sci., 44(2): 282.

Yoon, I. K. and M. D. Stern, 1995. Influence of direct-fed microbials on ruminal microbial fermentation and performance of ruminants: A review. Asian Australas. J. Anim. Sci., 8: 533-555.

Yousef, H. M., K. A. EI-Masry and A. L. Abou EI-Naga, 1996. Effect of dried Live yeast supplement on haemobiochemical 1evels and milk production responses of 1actating buffaloes, under hot summer condition in Egypt. Egyptian. J. Anim. Prod. 33: 11-21. 
تأثير إضافة البيوجين زنك على الآداء والهضم وتخمرات الكرش ويعض مكونات الدم في الجاموس

خالد إبراهيم إبراهيم زيدان'، أسامة مصطفى المالكي"، أسامة فرغلى كمنة"، مجدي عبد الرحمن

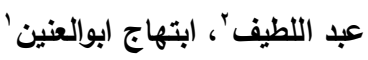

1- قسم بحوث تغنية الحيوان، معهج بحوث الإنتاج الحيواني، مركز البحوث النزاعية، الدقي، الجيزّة،

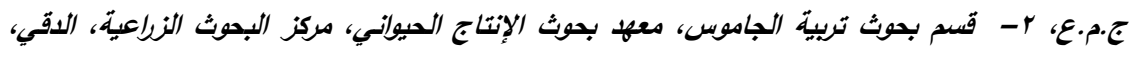

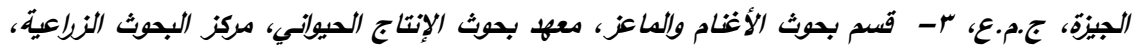

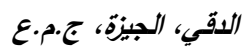

أجريت هذه التجربة في محطة بحوث الإنتاج الحيواني بالجميزة وكان الهدف من البحث هو دراسة تأثير

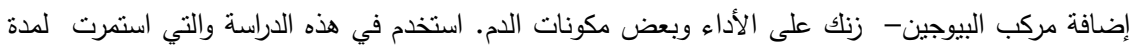

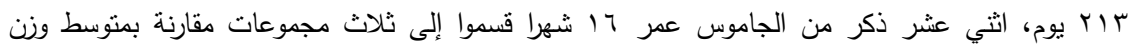

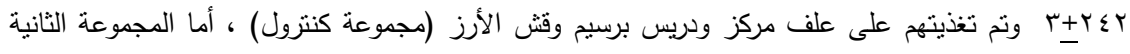

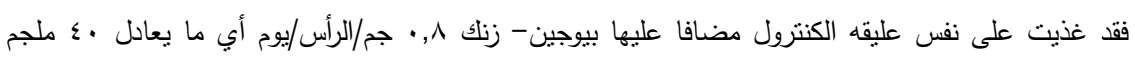

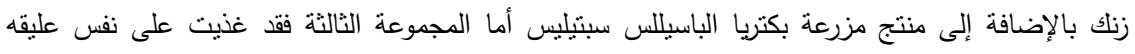

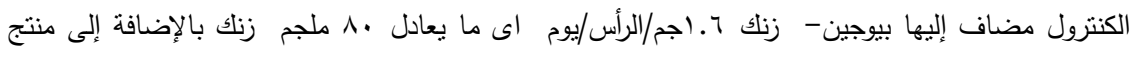
مزرعة البكتريا السابقة.

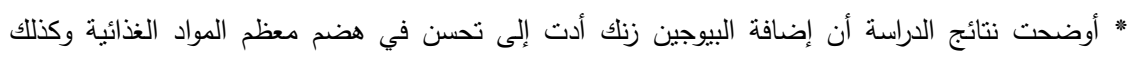

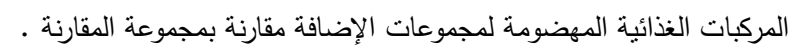

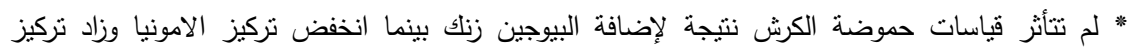

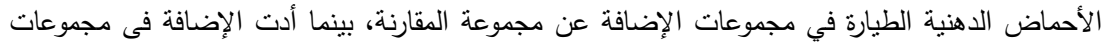

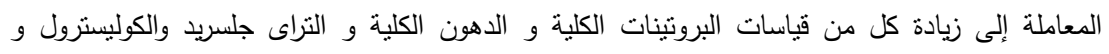
هورمون الثيروكسين وهرمون الثراى ايودو ثيرونين في الدم عن الكنترول.

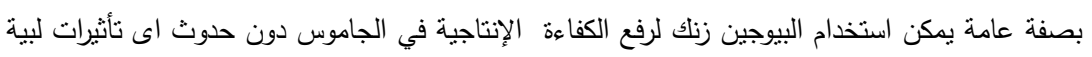

